\title{
SAUDAÇÃO PROFERIDA \\ PELO PROFESSOR YUSSEF SAID CAHALI AOS NOVOS TITULARES, PROFESSORES ROGÉRIO LAURIA TUCCI E CARLOS ALBERTO BITTAR
}

Minhas senhoras e meus senhores,

Estimados estudantes,

Mais uma vez aqui nos encontramos reunidos para o cumprimento de um dos rituais mais sublimes de nossa velha Academia de Direito; é o momento glorioso em que a Egrégia Congregação se reúne para acolher definitivamente em seu seio os novos professores; é o momento histórico da união do passado e do presente; é o momento em que a tradição e a modernidade se unem em indissolúvel amplexo.

Um celeiro de cultura jurídica acumulada no perpassar de quase dois séculos recebe, em oportunidade como esta, o aporte valioso de novos laureados da melhor doutrina, proclamando aos quatro cantos que aqui a perenidade do Direito é acalentada em sua evolução constante.

Quis o destino, em bálsamo benfazejo à nossa vaidade, fôssemos guindados à condição de representante da Egrégia Congregação, nesta posse festiva dos novos titulares, eminentes Professores Carlos Alberto Bittar e Rogério Lauria Tucci.

Deferência honrosa, esta que nos foi concedida, representa ela um tributo à amizade, ao respeito, à estima e admiração, que remarcam o nosso relacionamento que já se faz prolongado no tempo.

Esta satisfação se projeta redobrada diante da circunstância de que são dois os recipiendários, em plena igualdade de condições.

E que, pelas contribuições prestadas ao Direito, antes se completam por inteiro.

O Professor Carlos Alberto Bittar é recebido como Titular do Departamento de Direito Civil; o Professor Rogério Lauria Tucci é recebido como Titular do Departamento de Direito Processual. 
Um nos ensina e desbrava a vasta gama de direitos subjetivos que a ordem jurídica nos assegura; outro nos proporciona a indicação dos meios adequados para o pleno exercício desses mesmos direitos.

Já vai longe, esquecida nos escaninhos dos equívocos, a dialética dos confrontos que se pretendeu estabelecer, em visão sectária superada, a supremacia ou do direito material ou do direito processual.

É o retorno às origens: o direito sem a ação que o assegura, é simplesmente ineficaz; a ação sem o respectivo direito caracteriza-se pela inocuidade.

Nos dias atuais, não mais se concebe que o estudo do direito civil seja confinado em compartimento estanque; o civilista tem, necessariamente, de completar as suas pesquisas com incursões no âmbito do processo, pois só assim será compreendido e apreciado ao demonstrar como o direito se realiza; e a reciproca, da perspectiva própria, é igualmente verdadeira.

Os dois eminentes Mestres ora recebidos vivenciaram a problemática, superando-a com a exação; o currículo de cada um deles, ainda que sumariamente enunciado, é testemunho eloqüente e insofismável desta afirmação.

É também a certeza de que a nossa Congregação se enobrece e se enriquece ao receber os novos Titulares.

Carlos Alberto Bittar bacharelou-se pela nossa Faculdade de Direito em 1962, iniciando desde logo uma caminhada marcante na seara do direito, pontilhada de sucessivos êxitos, com a obtenção, com distinção, do título de Mestre em nossa Faculdade, em 1977; e já no ano seguinte, aqui se doutorava, na área de concentração de Direito Civil.

Professor por vocação, prestou seus relevantes misteres na Escola Superior de Administração de Negócios de São Paulo, na Escola Superior de Administração de Negócios de São Bernardo do Campo, nas Faculdades Metropolitanas Unidas, no Instituto Municipal de Ensino Superior de São Caetano do Sul, na Faculdade de Direito da Pontifícia Universidade Católica de São Paulo, na Fundação Educacional do Sul de Santa Catarina.

Mas terá sido em nossa Faculdade de Direito, que a sua atuação docente foi se projetando de maneira mais destacada, desde os primórdios de 1975, quando aqui começou como Professor Instrutor do Curso de Especialização. 
E sem prejuízo de uma intensa atividade participativa em cursos, conferências e seminários, do mais alto nível, no País e no exterior, aqui deu seqüência à sua carreira universitária, que já se divisava exitosa, obtendo o título de Livre-Docente com a sua notável tese sobre a responsabilidade civil nas atividades nucleares, até ser definitivamente consagrado com a titularidade ao defender com brilho a sua tese sobre dano moral.

É para nós difícil, como o seria certamente para qualquer dos oradores, uma apreciação, ainda que sucinta, da extensa obra jurídica do nosso homenageado, tal a diversidade de áreas em que a sua inteligência privilegiada transita com a mesma facilidade.

Diante da prodigalidade das obras que nos proporciona, torna-se dificil destacar, pelo superior gabarito que a todas caracteriza, a prevalência de seus trabalhos sobre direitos da personalidade, direitos do autor; direito da família, responsabilidade civil, contratos, direitos reais, direito da sucessão, direito comercial e empresarial, direitos do consumidor.

Todas elas se identificam pela atualidade e precisão de conceitos enunciados, fazendo de seu autor um dos mais requintados juristas da nova geração pátria.

Advogado bem-sucedido, seus méritos se completam com a sua recente nomeação, pelo quinto constitucional, para o nosso Primeiro Tribunal de Alçada Civil.

Não menos dignificantes as qualidades pessoais e culturais de Rogério Lauria Tucci.

É com particular apreço que acompanho de perto a evolução jurídica desta especial figura, seja na sua condição de advogado militante, seja na sua condição de professor.

Tão logo concluído em 1962 o curso de especialização do antigo sistema universitário, já nos proporcionando expressivos trabalhos jurídicos nas mais diversas áreas, já no ano seguinte Rogério Lauria Tucci já se apresentava a concurso de livre-docência desta Faculdade, com a monografia Da Contumácia no Processo Civil Brasileiro.

Membro do Instituto Brasileiro de Direito Processual Civil, teve participação marcante em diversos congressos realizados nesta área, sem descuidar de publicações didáticas e trabalhos de divulgação científica. 
Dentre as suas incontáveis obras, eu me permitiria destacar com a devida vênia, $D a$ Ação de Divórcio, de onde extraímos magníficos ensinamentos para nossos trabalhos de Direito de Família.

A sua atividade docente, sempre requisitada, não se restringiu à nossa Faculdade; também levou suas preciosas lições aos alunos das Faculdades Metropolitanas Unidas, da Associação de Ensino de Ribeirão Preto e da Faculdade de Direito Mackenzie.

Analisando a sua extensa produção científica, especialmente na área de processo, não há como destacar-se em qual dos aspectos dessa área o brilho de sua inteligência transparece com maior intensidade: se neste momento, o veterano $\mathrm{e}$ respeitável Mestre ascende à titularidade de processo penal, não é menos igualmente certo que as suas preciosas obras de processo civil estão definitivamente consagradas no cenário jurídico nacional.

Nós nos permitiriamos, porém, ressaltar, nesta oportunidade, as qualidades pessoais do advogado Rogério Lauria Tucci; e sob esse aspecto, sentimo-nos credenciados para dar testemunho pessoal do quanto Sua Excelência é respeitado pelos nossos Magistrados de todas as instâncias, seja pela seriedade de seu desempenho profissional seja particularmente pela sua conduta ilibada no exercício da advocacia.

Em síntese, e finalizando.

Hoje os nossos corações transbordam de alegria e a nossa Congregação se enriquece.

Acabamos de receber dois novos Professores Titulares que, ao lado da cultura jurídica que os exornam, apresentam ainda um ponto comum dos mais nobilitantes: são dois exemplares chefes de família.

Daí a saudação extensiva também aos seus ilustres familiares.

Muito obrigado. 